\title{
Benthic community structures in the North Sea
}

\author{
C. Heip \& J. A. Craeymeersch \\ Centre for Estuarine and Coastal Ecology, Netherlands Institute of Ecology; \\ Vierstraat 28, NL-4401 EA Yerseke, The Netherlands
}

\begin{abstract}
Coherent assemblages of marine benthic species have been recognized from the early twentieth century, and the classical papers of Petersen $(1914,1918)$ were based on studies of limited areas in the North Sea. In 1986, a synoptic survey of the North Sea north to $57^{\circ} \mathrm{N}$ was undertaken by a group of ten laboratories from seven North Sea countries. The results of this survey have recently been published (Heip et al., 1992a, b; Künitzer et al., 1992; Huys et al., 1992), and some of the results are summarized in this paper. The analysis of the macrofauna is based on slightly more than 700 taxa. In general, the North Sea macrofauna consists of northern species extending south to the northern margins of the Dogger Bank, and southern species extending north to the $100 \mathrm{~m}$ depth line. The central North Sea is an area of overlap of southern and northern species, especially around the $70 \mathrm{~m}$ depth contour. Consistent groupings of species are recognized that were summarized in seven faunal groupings. Macrofaunal body weight, density and diversity increase linearly towards the north. Macrofaunal biomass for the whole area averages $7 \mathrm{~g}$ adwt. $\mathrm{m}^{-2}$ and decreases from south to north. Distribution patterns and trends within the meiofauna were very different. Nematodes, which are the dominant taxon overall, are least abundant in the sandy sediments of the Southern Bight, then increase to a maximum around $53^{\circ} 30^{\prime} \mathrm{N}$ and slowly decrease again towards the north. Copepod density and diversity are highest in the Southern Bight, due to the presence of many interstitial species. A large number of species new to science were recorded by the North Sea Benthos Survey and about 1500 species are expected to occur. Copepods show very distinct assemblages according to water depth and sediment type. The contrasting patterns in latitudinal gradients of body weight and number of species of macro- and meiofauna can be only partially explained. Latitude and sediment characteristics, such as grain size and content in plant pigments, and water depth, determine part of the variance in species composition, density and biomass of the benthic fauna, but the patterns that are observed are different for different benthic groups, requiring careful consideration as to their use in biological monitoring procedures. Distributions are related to current patterns in the North Sea, annual temperature variations and availability of food. However, large parts of the variance in many parameters remain unexplained.
\end{abstract}

\section{INTRODUCTION}

Sediments in the North Sea are the habitat of perhaps three to five thousand species of macro- and meio-invertebrates. This habitat is characterized by extremely steep vertical gradients over length-scales of millimetres to centimetres, which contrast with extremely gentle horizontal gradients with characteristic length-scales of kilometres to tens of kilometres. In this seemingly homogeneous environment, characteristically tens to hundreds of species coexist on areas of a square metre or less. Partitioning of resources must be very finely-tuned to permit this high degree of coexistence. Food is often assumed to be the key factor in this partitioning. Many benthic animals are either bacterivores or predators, and benthic food webs are very complex, with super-abundant 1-mm large top-predators such as the turbellarians in the meiofauna. 
The sedimentary environment is unique, since there is, with a few exceptions, no insitu primary production. The organic material necessary for the maintenance, growth and reproduction of its inhabitants derives from primary production in the water column, to a far lesser degree from chemosynthetic processes, and mostly from advection of organic material produced elsewhere. Benthic biomass is a sensitive indicator of the amount of organic material that reaches the sediments, and integrates the outcome of the often very complex sedimentation and transportation processes. Benthic metabolism, as measured by oxygen uptake, is very variable and characteristically lies between 10 and $100 \mathrm{~g} \mathrm{C}$. $\mathrm{m}^{-2} \cdot \mathrm{a}^{-1}$, including bacterial metabolism. An important fraction of the energy flux through the North Sea ecosystem is sequestered in the sediments, from where it may be released as anything from methane and carbon dioxide to benthic biomass consumed by demersal fish or human being. If the whole carbon input in a sediment system were by living phytoplankton cells, and all animals were herbivores, one might estimate that the primary production of $100-250 \mathrm{~g} \mathrm{C} \cdot \mathrm{m}^{-2} \cdot \mathrm{a}^{-1}$ would be sufficient to permit a benthic biomass of $20-50 \mathrm{~g} \mathrm{C} \cdot \mathrm{m}^{-2}$. Although such high biomasses exist, the average value for North Sea sediments is about one order of magnitude lower. Detailed knowledge of these biomass values is important for input into, and validation of, ecological models, for ecotoxicological evaluations and for fisheries research.

Although the sedimentary system is as yet poorly understood and quantified, the benthos is increasingly used as a tool in biological monitoring of the marine environment. This is based on the observation that coherent assemblages of species are present over large areas. Changes in the relative abundance of species and a fortiori disappearance of species can be detected, because a multitude of sophisticated statistical techniques has been developed that allows the simultaneous treatment of many species abundances and the environmental variables, including pollutants. Most impact studies are local and cover relatively small areas, and results are only rarely put in a larger spatial or temporal frame. Both can be important, and the distinction between anthropogenic and natural variation is not easy to make. In this paper, some of the large-scale spatial trends in the North Sea will be described, as necessary background information for more localized studies.

\section{MATERIAL AND METHODS}

\section{Sampling}

The North Sea Benthos Survey was executed in April-May 1986 when 197 stations were sampled, covering the ICES grid from $51^{\circ} \mathrm{N}$ to $58^{\circ} \mathrm{N}$ and from $2^{\circ} 30^{\prime} \mathrm{W}$ to $8^{\circ} 15^{\prime} \mathrm{E}$. The boxes in the ICES grid are defined by the intersection of whole degrees longitude and half degrees latitude. The stations are on the four corners of the boxes and in the centre. At each of these stations, five box cores when possible, but sometimes Van Veen grabs, were taken. The complete list of replicates, dates, samples and stations has been reported to ICES (Anonymous, 1986) and is available from the authors on request. Most of the stations were analyzed for macrofauna biomass, density and species composition, for meiofauna density and copepod species composition, for sediment grain size analysis, protein content, plant pigment content, organic matter and a series of heavy metals.

The macrobenthos data presented here are based on the stations sampled during the ICES North Sea Benthos Survey, and selected stations of the northern North Sea. viz. 
those stations lying on an extrapolated ICES grid. The data from the northern North Sea have been gathered during eight Ministry of Agriculture. Fisheries and Food cruises from 1980 to 1985 (MAFF Survey) always in spring or early summer (Basford \& Eleftheriou, 1988; Basford et al., 1989; Eleftheriou \& Basford, 1989). The area covered extends between $56^{\circ} 15^{\prime} \mathrm{N}$ and $60^{\circ} 45^{\prime} \mathrm{N}$ and $3^{\circ} 30^{\prime} \mathrm{W}$ and $7^{\circ} 30^{\prime} \mathrm{E}$. A total of 119 stations were sampled for macrofauna (Basford et al., 1990).

\section{Statistical analysis}

Measures of species diversity

The following Hill's diversity numbers (Hill, 1973) were used as measures of diversity of the copepod community in the meiofauna and the mollusks, echinoderms, polychaetes and crustaceans in the macrofauna. They were calculated on the raw data:

$\mathrm{N}_{0}=$ the number of species in the sample (species richness); equals in the study of the meiofauna the "copepod density" (number of species per unit area $=10 \mathrm{~cm}^{2}$ ), as all copepods in the sample were identified; $\mathrm{N}_{1}=\exp \left(\mathrm{H}^{\prime}\right)$, with $\mathrm{H}^{\prime}$ the Shannon-Wiener diversity index calculated with neperian logarithms.

\section{Classification}

TWo-way INdicator SPecies ANalysis (Hill, 1979) was used to classify the stations for which species were determined. TWINSPAN is a polythetic divisive technique that first performs a primary ordination on the samples by reciprocal averaging, and then uses this ordination to obtain a classification of the species according to their ecological preferences. The synecological relations of the various species can be expressed in an ordered two-way table constructed from the sites-by-species matrix. TWINSPAN also identifies one to several differential species which are particularly diagnostic of each division (twin group) in the dendrogram (indicator ordination).

\section{RESULTS}

\section{Species assemblages}

Künitzer et al. (1992) describe the macrofauna communities from the North Sea Benthos Survey and the MAFF Surveys as based on a TWINSPAN classification using either presence/absence or density data. They describe eight different assemblages. At the first dichotomy, most stations north of the Dogger Bank were separated from the stations south of the $70 \mathrm{~m}$ depth contour. At the second dichotomy, the stations south of the $70 \mathrm{~m}$ depth contour were divided along the $30 \mathrm{~m}$ depth contour into those with a sediment of fine sand and with a depth generally greater than $30 \mathrm{~m}$, and those with coarser sediment mainly shallower than $30 \mathrm{~m}$. The stations north of the $70 \mathrm{~m}$ depth contour were further divided mainly by the $100 \mathrm{~m}$ depth contour into stations in the central north Sea and those in the northern North Sea. The TWINSPAN-analysis based on species abundance gave much the same results: the first dichotomy occurs again along the $70 \mathrm{~m}$ depth contour, the second dichotomy separates coarse from fine sand stations both in the south and in the north.

A list of the most frequent species of every TWIN group described by Künitzer et al. 
Table 1. Number of stations in each TWIN group at which a species has been found (based on species abundance data) for the ten most frequent species

TWIN Ia (54 stations)

44. Spiophanes bombyx

41 Bathyporeia elegans

41 Nephtys cirrosa

41 Scoloplos armiger

38 Ophelia borealis

38 Spio filicornis

36 Echinocardium cordatum

35 Magelona sp.

31 Lunatia poliana

30 Bathyporeia guilliamsoniana

TWIN Ib (19 stations)

19 Ophelia borealis

16 Aonides paucibranchiata

14 Scoloplos armiger

11 Chaetozone setosa

11 Echinocyamus pusillus

11 Phoxocephalus holbolli

11 Pisione remota

10 Bathyporeia elegans

9 Abra prismatica

9 Spiophanes bombyx

TWIN II a (40 stations)

38 Amphiura filiformis

38. Nephtys hombergii

37 Pholoe sp.

36 Phoronis sp.

35 Chamelea gallina

35 Mysella bidentata

35 Nucula nitidosa

34 Lunatia poliana

33 Echinocardium cordatum

33 Spiophanes bombyx

TWIN IIb (62 stations)

57 Spiophanes bombyx

54 Pholoe sp.

53 Amphiura filiformis

53 Goniada maculata

53 Scoloplos armiger

49 Mysella bidentata

45 Phoronis sp.

44 Bathyporeia elegans

$44 \quad$ Nephtys longosetosa

43 Magelona sp.
TWIN IIIa (47 stations)

$\begin{array}{ll}44 & \text { Goniada maculata } \\ 44 & \text { Myriochele sp. } \\ 40 & \text { Amphiura filformis } \\ 38 & \text { Scoloplos armiger } \\ 38 & \text { Spiophanes bombyx } \\ 36 & \text { Spiophanes kroyeri } \\ 35 & \text { Nephtys hombergii } \\ 31 & \text { Antalis entalis } \\ 31 & \text { Pholoe sp. } \\ 30 & \text { Chaetozone setosa }\end{array}$

TWIN IIIb (45 stations)

41 Spiophanes kroyeri

40 Prionospio cirrifera

38 Pholoesp.

$37 \quad$ Myriochele sp.

35 Thyasira sp.

34 Levinsenia gracilis

33 Amphiura filiformis

32 Owenia fusiformis

30 Notomastus latericeus

29 Aricidea catherinae

TWIN IVa (12 stations)

11 Sphaerosyllis bulbosa

10. Echinocyamus pusillus

9 Aonides paucibranchiata

9 Exogone hebes

9 Ophelia borealis

8 Hesionura elongata

8 Polycirrus sp.

8 Spiophanes bombyx

7 Abra prismatica

7 Angulus pygmeus

TWIN IVb (2 stations)

2 Aonides paucibranchiata

2 Glycera lapidum

2 Hesionura elongata

2 Pisione remota

2 Protodorvillea kefersteini

1 All other species 
Table 2. Average density (ind. $\mathrm{m}^{-2}$ ) per TWIN group of the ten most abundant species. Number of stations in each TWIN group as for Table 1

TWIN Ia

70 Bathyporeia elegans

69 Magelona sp.

53 Scoloplos armiger

$48 \quad$ Urothoe poseidonis

36 Ophelia borealis

34 Angulus fabulus

$31 \quad$ Nicomache sp.

28 Spisula subtruncata

$27 \quad$ Bathyporeia guilliamsoniana

27 Spiophanes bombyx

TWIN Ib

128 Pisione remota

71 Protodorvillea kefersteini

60 Ophelia borealis

43 Goniadella bobretzkii

36 Scoloplos armiger

36 Aonides paucibranchiata

23 Branchiostoma lanceolatum

21 Goodallia triangularis

21 Echinocyamus pusillus

18 Chaetozone setosa

TWIN IIa

469 Amphiura filiformis

$270 \quad$ Mysella bidentata

112 Myriochele sp.

95 Phoronis sp.

91 Pholoe sp.

91 Magelona sp.

70 Scoloplos armiger

51 Chamelea gallina

50 Spiophanes bombyx

$43 \quad$ Nucula nitidosa

TWIN IIb

$\begin{array}{ll}93 & \text { Spiophanes bombyx } \\ 85 & \text { Bathyporeia elegans } \\ 81 & \text { Amphiura filiformis } \\ 56 & \text { Magelona sp. } \\ 55 & \text { Mysella bidentata } \\ 51 & \text { Phoronis sp. } \\ 49 & \text { Myriochele sp. } \\ 38 & \text { Scoloplos armiger } \\ 34 & \text { Anthozoa indet. } \\ 29 & \text { Ophiura albida }\end{array}$

TWIN IIIa

333 Myriochele sp.

131 Amphiura filiformis

48 Diastylis lucifera

25 Scoloplos armiger

20 Goniada maculata

20 Eudorella emarginata

17 Spiophanes bombyx

15 Mysella bidentata

14 Spiophanes kroyeri

12 Rhodine gracilior

TWIN IIIb

215 Thyasira sp.

195 Capitellidae indet.

158 Myriochele sp.

123 Ophiuroidea indet.

114 Spiophanes kroyeri

112 Owenia fusiformis

81 Prionospio cirrifera

68 Pholoe sp.

65 Paradoneis lyra

62 Amphiura filiformis

TWIN IVa

$344 \quad$ Ophelia borealis

139 Exogone hebes

108 Glycera lapidum

93 Prionospio malmgreni

81 Echinocyamus pusillus

78 Ophiuroidea indet.

58 Sphaerosyllis bulbosa

48 Spiophanes bombyx

48 Sipunculida indet.

46 Pisione remota

TWIN IVb

145 Pisione remota

135 Protodrilus sp.

75 Glycera lapidum

71 Echinocyamus pusillus

71 Sabellidae indet.

45 Aonides paucibranchiata

45 Goniada norvegica

40 Owenia fusiformis

35 Hesionura elongata

25 Sipunculida indet. 
(1992) is given in Table 1. A list of the ten most abundant species per TWIN group is given in Table 2.

Huys et al. (1992) describe the copepod communities from the North Sea Benthos Survey. The first dichotomy in the TWINSPAN-analysis separated the deep water samples from the shallow stations. The second dichotomy of the shallow water cluster divided the stations into two secondary clusters of equal size (55 stations), corresponding to twin groups $\alpha$, TWIN A and TWIN B, and to TWIN $C$ and $\beta$, respectively. The secondary division of the deepwater cluster results in two more twin groups, TWIN D and TWIN E. TWIN A represents perhaps the most distinctive community found in the North Sea. It consists of 22 highly diverse stations located in the area traditionally referred to as the Southern Bight with sediments consisting of fine $(<250 \mu)$ to medium coarse $(250-500 \mu)$ sandy sediments with a low silt clay content. The Southern Bight (19 stations) harbours approximately $50 \%$ of the total number of species found during the NSBS. TWIN B essentially contains shallow stations with fine to very fine sandy sediments with a low amount of silt and clay. The fauna was characterized by a mixture of minute interstitial species (Leptastacidae) and large burrowing forms (Ectinosomatidae). TWIN C reflects a transition community between the coastal Ectinosomatidae-Leptastacidae association (TWIN B) and the deepwater community (TWIN D) north of the Dogger Bank. This station-group consisted of 51 stations and was impoverished, both qualitatively and quantitatively. TWIN D is a heterogeneous cluster of 48 stations and coincides with the northern part of the North Sea, situated between the Norwegian Deeps and the Scottish coastline. No proper indicator species could be identified for the group, but the most important families, both in terms of diversity and density, were the Cletodidae, Zosimidae and Idyanthidae. These three families nearly always occurred together in every station of the area. TWIN E corresponds to the northeastern part of the study area (Norwegian Deeps). The community was dominated by the families Cletodidae and Ancorabolidae, and by the deepwater species Pseudotachidius coronatus (Pseudotachidinae).

In Figure 1, a summary of the results of Künitzer et al. (1992) and Huys et al. (1992) is given. In this figure, the TWIN groups of both papers have been summarized in three groups. In order to compare the macrobenthos and copepod community structure, a separate TWINSPAN-analysis of the macrobenthos stations south of $58^{\circ} \mathrm{N}$ was performed. Three TWIN-groups were defined (Fig. 1a). The copepod TWIN-groups $\alpha, A$ and $B$ were combined in group I, TWIN-groups $\beta$ and C in group II, and TWIN-groups C and D in group III (Fig. 1b). Both the copepods and the macrofauna are divided into clusters along more or less the same depth contours: macrobenthos is divided at the $30 \mathrm{~m}$ and $55 \mathrm{~m}$ depth contour, copepods at the 40 and $50 \mathrm{~m}$ depth contour. No attempt was made to compare both analyses statistically. We simply superimposed both figures, and gave stations analysed for macrobenthos and copepods a different symbol, according to whether they fell into the same TWIN-group or not. From Figure 1c, it is clear that the three TWIN-groups more or less cover the same area. On a total of 158 stations, 48 belong to a different cluster. Differences appear at the transition zones and along the Scottish and English coasts.

\section{Species distributions}

The macrofaunal species with the highest frequencies of occurrence in the North Sea are Spiophanes bombyx, Pholoe sp., Goniada maculata and Amphiura filiformis. They 

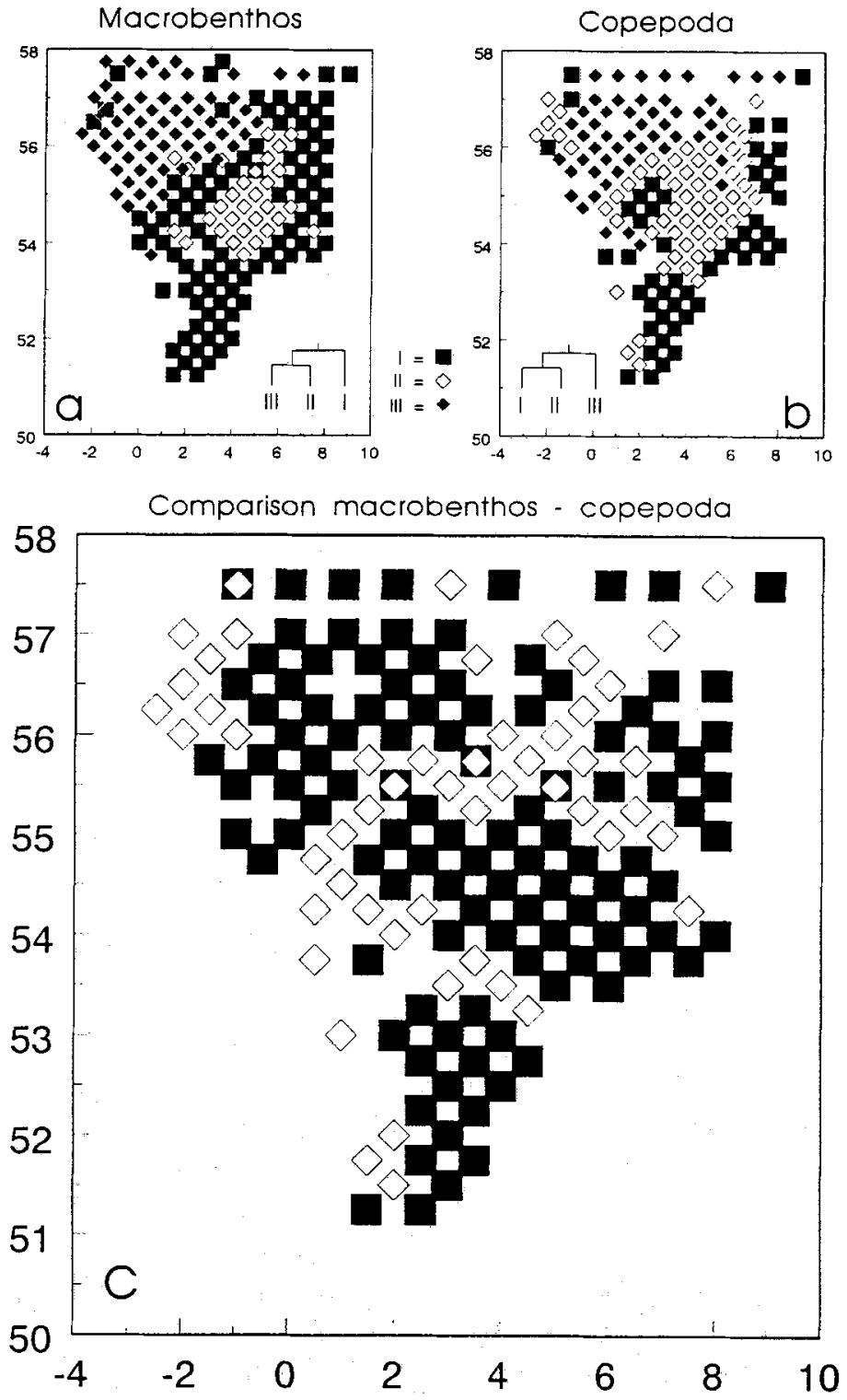

Fig. 1. TWINSPAN-analyses for (a) total macrofauna, (b) copepods; (c) similarity between macrofauna and copepods as revealed by these analyses 
Table 3. The thirty most frequent macrobenthic species of the North Sea Benthos Survey and the MAFF Survey combined ( $N=$ the number of stations at which a species has been found; the total number of stations was 281)

\begin{tabular}{|c|c|}
\hline $\mathrm{N}$ & Species \\
\hline 217 & Spiophanes bombyx \\
\hline 196 & Scoloplos armiger \\
\hline 188 & Pholoe sp. \\
\hline 185 & Goniada maculata \\
\hline 183 & Amphiura filiformis \\
\hline 161 & Nephtys hombergii \\
\hline 159 & Chaetozone setosa \\
\hline 147 & Phoronis sp. \\
\hline 143 & Owenia fusiformis \\
\hline 136 & Myriochele sp. \\
\hline 132 & Mysella bidentata \\
\hline 130 & Ophelia borealis \\
\hline 127 & Bathyporeia elegans \\
\hline 122 & Lunatia poliana \\
\hline 122 & Magelona sp. \\
\hline 109 & Nephtys longosetosa \\
\hline 108 & Echinocardium cordatum \\
\hline 107 & Abra prismatica \\
\hline 107 & Spiophanes kroyeri \\
\hline 106 & Ophiura albida \\
\hline 105 & Harpinia antennaria \\
\hline 105 & Spio filicornis \\
\hline 97 & Sthenelais limicola \\
\hline 92 & Amphictene auricoma \\
\hline 91 & Notomastus latericeus \\
\hline 89 & Chamelea gallina \\
\hline 89 & Phaxas pellucidus \\
\hline 86 & Arctica islandica \\
\hline 85 & Aonides paucibranchiata \\
\hline 85 & Tellimya ferruginosa \\
\hline
\end{tabular}

occur widely at nearly all depths and in a wide variety of sediments. A list of the thirty most frequent species of the North Sea is given in Table 3.

Indicator and preferential species of the TWINSPAN analysis of the macrofauna show either one of three distribution types. Most species are either distributed south of a parallel to the northern edge of the Dogger Bank $(50 \mathrm{~m}$ depth contour) or north of it. Species with a southern distribution may occur also in the central North Sea but never north of the $100 \mathrm{~m}$ contour at 57-58 ${ }^{\circ} \mathrm{N}$ : examples are Ophiura albida, Echinocardium cordatum, Chamelea gallina and Tellimya ferruginosa. Some of these species mainly occur in the central North Sea, like Chaetoderma nitidulum and Ampelisca tenuicornis. Species with a northern distribution were usually never found south of the $50 \mathrm{~m}$ depth contour, e.g. Ophiura affinis, Montacuta substriata, Antalis entalis and Minuspio cirrifera.

Some species are restricted to certain sediment types. On coarse sediments, 
Echinocyamus pusillus, Pisione remota, Glycera lapidum and Spisula elliptica occur all over the North Sea, while Sphaerosyllis bulbosa and Glycera celtica are restricted to coarse sediments along the Scottish coast, and Polycirrus medusa and Phoxocephalus holbolli are restricted to coarse sediments in the south and east of the North Sea. On fine sands, Aricidea minuta, Bathyporeia elegans and Ophelia borealis occur all over the North Sea, but Bathyporeia guilliamsoniana, Fabulina fabula, Urothoe poseidonis and Sigalion mathildae were only found in the southern North Sea on fine sand at depths of less than $30 \mathrm{~m}$. Sediments of muddy fine sand occur mainly in the southern North Sea at 30-50 m depth and in the west of the northern North Sea. Species with a wide distribution on this sediment are Eudorella truncatula, Glycinde nordmanni and Harpinia antennaria. Callianassa subterranea, Nucula nitidosa, Chaetopterus variopedatus and Synelmis klatti are restricted to the southern North Sea and Leucon sarsi, Thyasira ferruginea, Laonice sarsi and Molgula sp. are restricted to the northern North Sea.

Nematodes were, almost without exception, the dominant group in the meiofauna. Only in the Southern Bight were harpacticoids sometimes as abundant as nematodes, or were even the dominant taxon of the meiofauna. In the remaining localities, nematodes accounted for at least $85 \%$ of the meiofauna; Harpacticoida or Turbellaria (and in a few cases Gastrotricha) ranked second in abundance. The other groups were present especially in medium coarse or coarse sands; but they were far less common than the main taxa.

A total number of 278 species of copepods was found, belonging to 105 genera and 22 families. 121 species are new to science! The total number of species known from the North Sea has doubled due to the NSBS. It can be estimated that at least 1500 species of benthic copepods exist in the North Sea, if one includes the rocky shores. Copepod species distributions have not been studied in detail. However, striking patterns are observed even when using copepod families. The vast majority of the fauna belonged to the Harpacticoida. The Cyclopoida were represented by the primarily mesopsammic family Cyclopinidae (6 species). An additional number of calanoids and planktonic cyclopoids (Oithonidae) was omitted in the analysis.

Qualitatively important families were Paramesochridae (44 species), Cylindropsyllidae (38), Ameiridae (35), Ectinosomatidae (34), Cletodidae (26), Laophontidae and Diosaccidae (21). A total number of 105 genuinely interstitial species were recorded, including the Paramesochridae, Cylindropsyllidae, Cyclopinidae and small-sized representatives of the Ameiridae, Canthocamptidae, Diosaccidae and Ectinosomatidae. The remainder consisted mainly of large epibenthic or burrowing harpacticoids. Euterpina acutifrons and Microsetella norvegica are likely to be derived from the plankton.

\section{Abundance and biomass}

In nearly all stations, nematodes are the dominant meiofauna group. Their densities ranged from 61 to 4167 ind. $10 \mathrm{~cm}^{-2}$. The average density over all stations was 759 ind. $10 \mathrm{~cm}^{-2}$. They become especially dominant from $54^{\circ}$ north, although there is no linear trend in nematode density with latitude. Of course meiofauna density closely parallels nematode density.

There is a distinct and significant trend for copepod density to decrease towards the north. Highest values (181 ind. $10 \mathrm{~cm}^{-2}$ ) were recorded in the Southern Bight between 


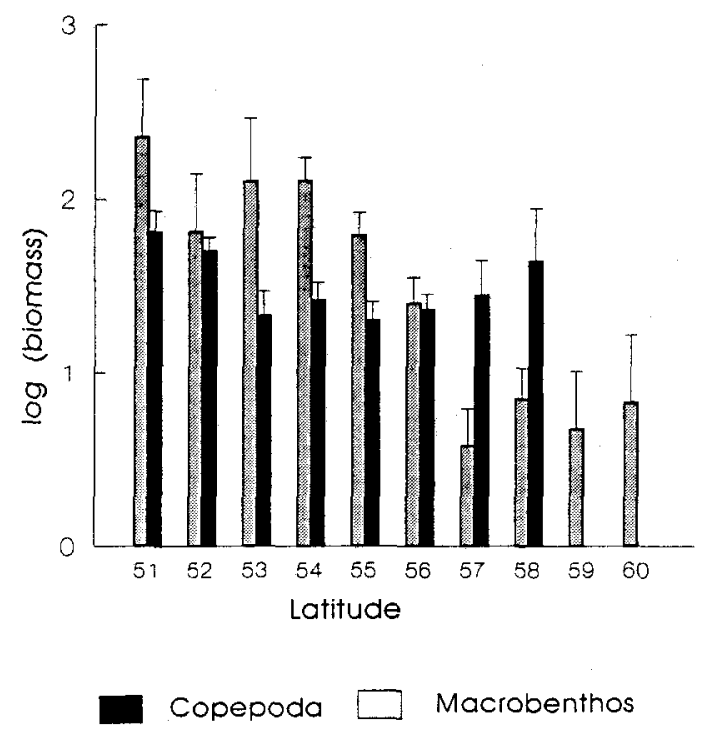

Fig. 2. Biomass of macrofauna (ln g AFDW. $\left.\mathrm{m}^{-2}\right)$ and copepods $\left(\log \mu \mathrm{g}\right.$ AFDW. $\left.10 \mathrm{~cm}^{-2}\right)$ as a function of latitude

$51^{\circ} 30^{\prime}$ and $52^{\circ} \mathrm{N}$, where tiny interstitial copepods showed an overwhelming dominance in the community. Density decreased rapidly towards the Dogger Bank and reached its minimum averaged value (18 ind. $10 \mathrm{~cm}^{-2}$ ) in the Norwegian Deeps.

Macrofaunal density shows a less distinct trend with latitude. Although the highest densities are found in the north (around 2500 ind. $\mathrm{m}^{-2}$ ) and the lowest in the south (around 800 ind. $\mathrm{m}^{-2}$ ), there is no linear trend inbetween. Moreover the values are biassed, since for the northern stations a smaller mesh width was used for sieving.

Copepod biomass (Fig. 2) shows a bimodal pattern, with highest values in the south and the north.

The average total macrofauna biomass over all stations is $7 \mathrm{~g} \mathrm{AFDW} \cdot \mathrm{m}^{-2}$. Rachor (1982) summarized available biomass values, and estimated the biomass as $3.2 \mathrm{~g}$ AFDW $\cdot \mathrm{m}^{-2}$. This value corresponded to the stock as used in the North Sea model of Andersen \& Ursin (1977), but was already about twice as high as biomass values used by Steele $(1967,1974)$. Total biomass (after log transformations) shows a clear and significant trend with latitude (Heip et al., 1992a). Biomass decreases considerably towards the north (Fig. 2). This major shift is not caused by one major taxonomical group overtaking another as one goes north. Rather, the same trends seem to be operating in the different groups.

\section{Body weight}

The mean weight of the individuals, obtained by dividing total biomass by total density in each sample, also shows a very clear gradient with latitude. However, meioand macrofauna display opposite trends (Fig. 3). In the macrofauna towards the northern part of the North Sea, individual size becomes considerably smaller: the difference in mean weight is much greater than one order of magnitude. The variation in mean 


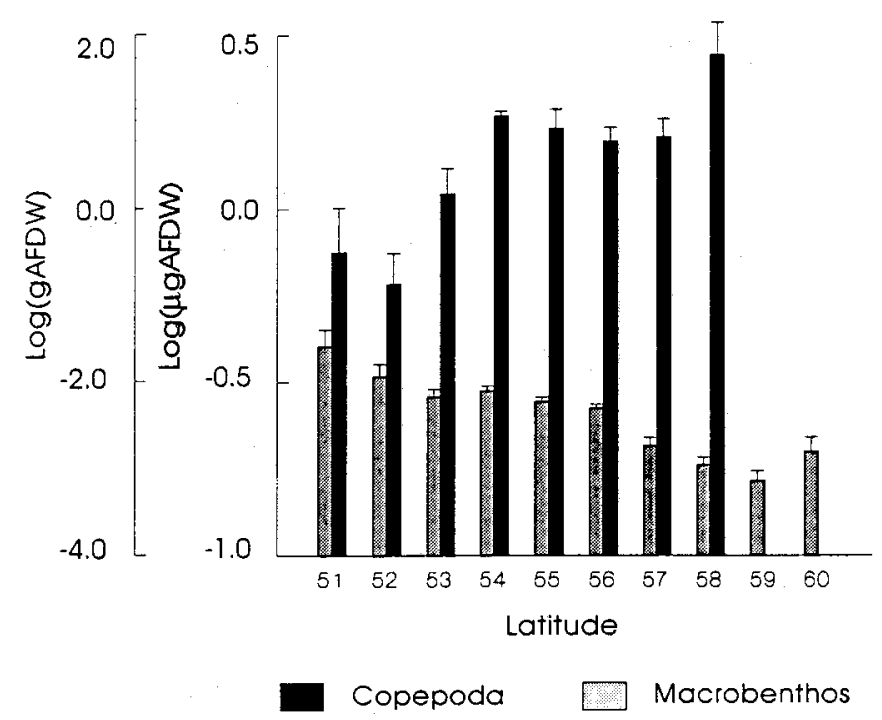

Fig. 3. Individual weight of macrofauna (log gAFDW) and copepods (log $\mu$ g AFDW) as a function of latitude

biomass per assemblage is very high. The mean biomass is lowest in the northern North Sea (groups IIIb and IV). The biomass increases towards the shallower southern North Sea and reaches highest values south of the Dogger Bank (group Ia, IIa). In the meiofauna, the opposite occurs. For copepods the individual size increased considerably, due to the gradual replacement of interstitial by large epibenthic species towards the north. The mean ash free dry weight of the nordic species was nearly three times the value of the Southern Bight species. This difference in AFDW combined with the latitudinal trend displayed by density explains why total biomass reaches a peak in both the south and the north. In the Southern Bight, low individual size and weight are compensated by maximum density values; in the northern North Sea large, epipelic species with strongly chitinized exoskeletons (e.g. Cletodidae) occurred in low to very low numbers.

\section{Diversity}

Diversity $\mathrm{N}_{1}$ (expressed in equivalent number of species) calculated on the total sample showed a similar trend with latitude. Again, opposing trends are noted in the macrofauna and copepods within the meiofauna (Fig. 4). For the copepods, this trend is most distinctive in the Southern Bight with an average of 38 species found in the southern stations off the Belgian coast and only 13 species south of the Dogger Bank. In the northern North Sea, diversity showed a tendency contrary to the density trend. The low number of species recorded between $57^{\circ}$ and $58^{\circ} \mathrm{N}$ approximately coincides with the $100 \mathrm{~m}$ isobath. For the macrofauna there is a regular increase of diversity, at least between 51 and $58^{\circ} \mathrm{N}$, which also exists within the four main macrofaunal groups (Fig. 5). Mollusk diversity seems to peak at $56^{\circ} \mathrm{N}$, whereas echinoderm and annelid diversity increases more to the north. 


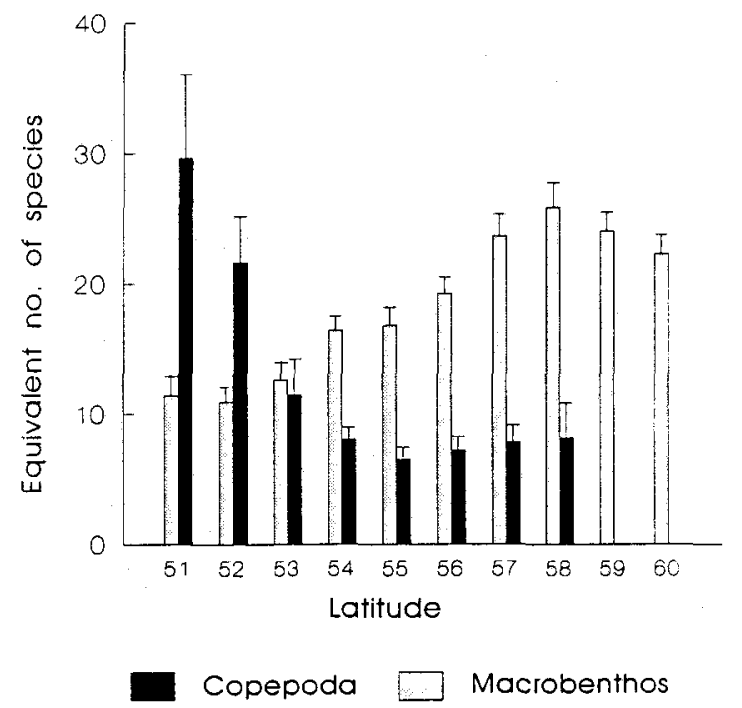

Fig. 4. Diversity of macrobenthos and harpacticoid copepods (Hill $\mathrm{N}_{1}$ expressed in equivalent number of species) as a function of latitude

\section{DISCUSSION}

\section{Species assemblages}

The main patterns of macrobenthic species distributions show that the bottom fauna of the North Sea is composed of northern elements, that do not extend further south than the north of the Dogger Bank, and southern elements going not further north than the $100 \mathrm{~m}$ contour. Northern and southern species therefore mix in the central North Sea, and northern and southern assemblages overlap along the $70 \mathrm{~m}$ contour (Künitzer et al., 1992). The occurrence of cold water species north of the Dogger Bank and of warm water species in the southern North Sea was already recognized by Ursin (1960), Kirkegaard (1969) and Petersen (1977). None of these authors, however, showed that the southern species occurred as far north as the 70-100 $\mathrm{m}$ depth contour.

The separation of the macrobenthic infauna into a northern and a southern one along the $70 \mathrm{~m}$ contour might be a result of the current pattern in the North Sea. Most of the Fair Isle-Orkney inflow of Atlantic water moves eastwards at about $57^{\circ} 30^{\prime} \mathrm{N}$ and only part of it travels southwards down the coast of England (Lee, 1980). The shallow southern North Sea is, in contrast to the deeper northern areas, influenced by the English Channel which extends up to the Dogger Bank. The northern North Sea and part of the central North Sea are therefore influenced by a different water mass than the rest of the North Sea.

Another factor determining the distribution of assemblages is the annual variation of temperature in bottom waters. Large areas of the southern North Sea are not stratified during most of the year (Tomczak \& Goedecke, 1962), while in the stratified areas north of the Dogger Bank summer temperatures are less than $7^{\circ} \mathrm{C}$. In winter the southern North Sea is colder $\left(4^{\circ} \mathrm{C}\right)$ than the rest of the North Sea $\left(5-7^{\circ} \mathrm{C}\right)$. These differences in 

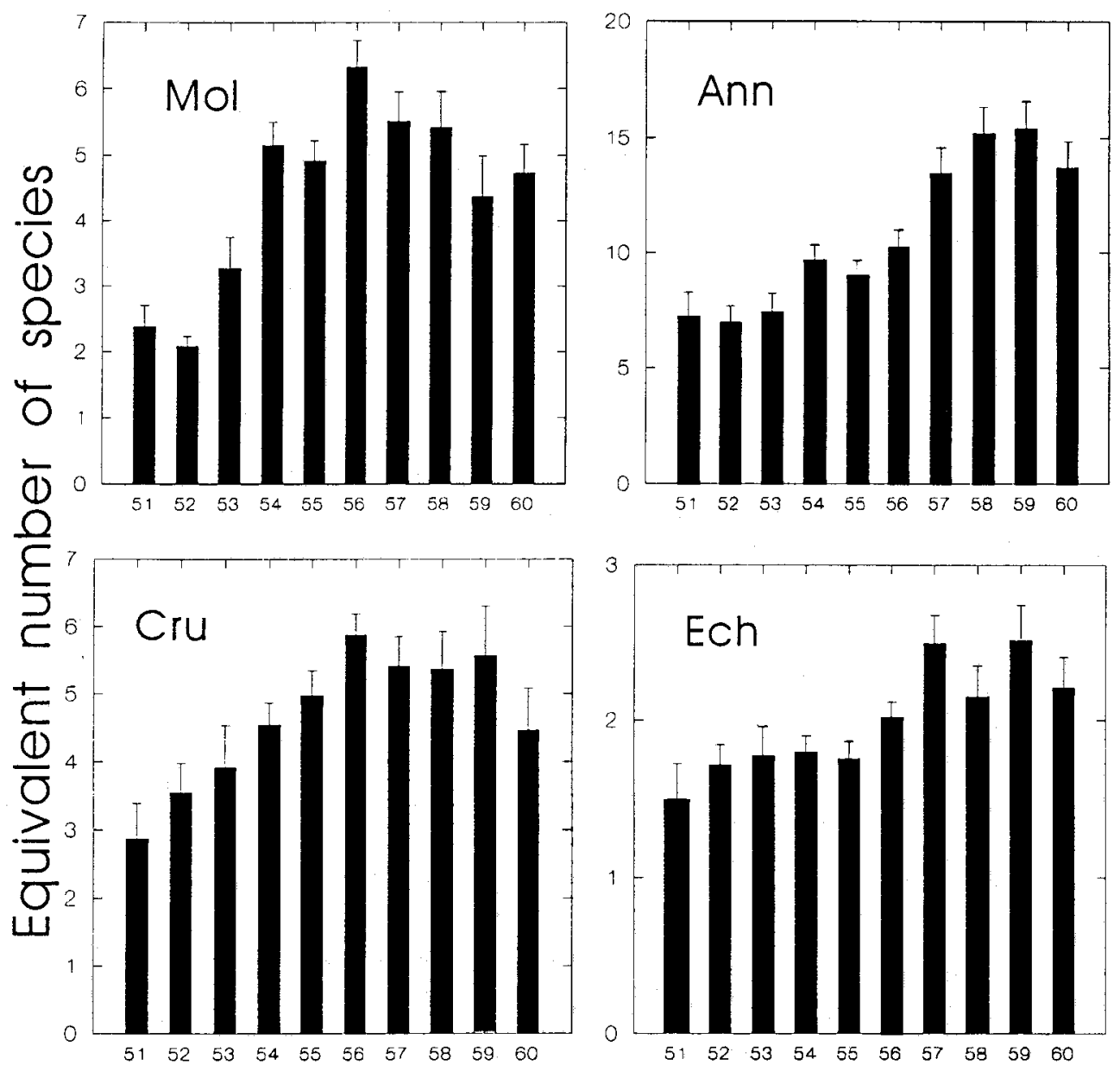

latitude

\section{latitude}

Fig. 5. Diversity of taxonomic groups (Hill number $\mathrm{N}_{1}$ expressed in equivalent number of species) as a function of latitude. Mol: Mollusca; Ann: Annelida; Cru: Crustacea; Ech: Echinodermata

temperature north and south of the Dogger Bank might explain why cold water species do not go farther south than the Dogger Bank. The reason why warm species are not found below 70-100 m depth, although they survive the cold summer temperatures in the central North Sea, might lie in the general current pattern.

A third factor which may cause the differences among the macrofaunal assemblages is the availability of food. Large stocks of pelagic copepods only develop in the northern North Sea. They consume the summer production of phytoplankton (Fransz \& Gieskes, 1984). The faecal pellets, being recycled higher in the water column, do not reach the deep water (Krause, 1981), thus limiting this source of food to the benthos in the summer months. This could explain the low biomass of infauna in the northern North Sea. Farther 
south, main parts of the phytoplankton production reach the bottom, resulting in a better food supply to the benthos, especially in summer months.

It appears that sediment characteristics are the main determinants in explaining the distribution of copepods in the relatively shallower parts of the southern North Sea. In the northern parts and in stations deeper than $80 \mathrm{~m}$, depth is the main factor in explaining copepod distribution. In general, copepods show a clear response to the known environmental variables. Grain size has often been regarded as the most significant parameter influencing the distribution of meiofauna. The distribution of the interstitial families of Copepoda in the North Sea in general confirms the importance of sediment grain size. However, for the Leptastacidae, grain size per se does not affect their distribution. The genera Leptastacus and Paraleptastacus which are generally regarded as interstitial sliders (Wells, 1986) do not seem to be affected by the amount of silt which might fill up the interstitial spaces of coarser sands, nor by the actual grain size of the sand fraction. The Leptastacidae are the only vermiform copepods whose distribution extends to the central North Sea, perhaps because they are specialised feeders, possessing large glands that produce long mucus strands in which high numbers of rod-shaped bacteria, small diatoms and unidentifiable debris are trapped (Huys, 1992).

In general, the picture one obtains for the benthic communities of the North Sea is rather similar when using either total macrofauna or copepod species, despite the fact that many of the latitudinal trends in the two groups diverge and that the taxonomic level of analysis is not strictly comparable.

\section{Latitudinal trends}

Trends in individual body weight or in diversity on a global scale have been documented mainly for fauna from the terrestrial environment; but why these trends exist is not really understood (Clarke, 1992). Thorson (1957) noted a pronounced increase in the species richness of epifauna from hard substrates towards the tropics, but the number of macrofaunal species in sediments appeared to be roughly the same for arctic, temperate and tropical areas. On the other hand, Stehli et al. (1967) clearly demonstrated a diversity trend of bivalve mollusks at species, genus and family level from the tropics to the poles, and in a later study (Stehli et al., 1972, cited in Clarke, 1992) demonstrated the same for foraminiferans. These appear to be the only detailed work on the problem of diversity trends, and, since both groups form calcareous skeletons, Clarke (1992) suggests that perhaps such trends do not exist in other taxa. In our study it is clearly demonstrated that trends in several characteristics do indeed exist on large scales (about $1000 \mathrm{~km}$ ), but that these trends can vary in different groups (meio- versus macrofauna). It is interesting to note that within the macrofauna the trend is similar in all taxonomic groups and that it is contrary to what would be expected, i.e. increases are observed towards the north. However, since temperature is considered a key factor, it must be observed that average bottom temperatures of the North Sea probably increase towards the north over the area studied.

\section{Benthic communities and biological monitoring}

The utility of benthic communities as tools for biological monitoring of the marine environment is now generally accepted. The confirmation that the entire North Sea may 
be subdivided into areas based on benthic species composition is important in view of the management of the North Sea, since it permits choices of representative stations to be made. Spatial patterns are sufficiently constant to permit prediction. However, to increase predictive strength, the causal mechanisms leading to changes in size and relative abundance have to be better understood at several levels of organization. Basic information is needed on genetics, biochemistry and physiology for most benthic species. Data on energy flow (food uptake, growth and reproduction, respiration and excretion) and life-cycle strategies, as determined by natural selection, do not exist - even for many dominant macrofauna species, and for nearly all marine meiofauna.

Ecological models investigating the role of disturbance in explaining diversity of benthic communities should be elaborated. The role of competition and predation in subtidal benthic communities is scantly known and not quantified at all. Ecological models should include the planktonic (larval) phase of benthic macroinvertebrates and recruitment processes. Models of carbon flow through complete marine systems should take the diversity of benthic structure and functioning and the complexity of the benthic food web into account.

Much more effort should be put into the study of relationships between benthic animals and their aquatic and sedimentary environment. Processes such as bioturbation, the role of feeding processes, tube-building and burrowing activities, the production of mucus etc. in regulating the geochemical properties of the sedimentary environment and its physical characteristics have hardly been studied at all. Only when a good description of the physical, chemical and biological processes - and their interrelationships governing the mass transfer from pelagic to benthic systems and early diagenesis are available, will it be possible to relate results from chemical behaviour of pollutants, ecotoxicological tests and hydrodynamic or atmospheric dispersal models.

Acknowledgments. The vessels which participated in the North Sea Benthos Survey were the R. V.'s "Littorina" (University of Kiel), "Friedrich Heincke" (Biologische Anstalt Helgoland), "Senckenberg" (Senckenberg Institute, Wilhelmshaven), "Victor Hensen" (Institut für Meeresforschung [now Alfred Wegener Institute], Bremerhaven), "Aurelia" (Netherlands Institute for Sea Research), "Tyro" (Netherlands Marine Research Foundation), "Holland" (Rijkswaterstaat) and "Belgica" (Belgian Ministry of Public Health). We gratefully acknowledge the help of the different authorities in providing us with ship-time, and the crews of all these vessels. We are also grateful to the North Sea Directorate of the Ministry of Public Works and Transport (Rijkswaterstaat) in the Netherlands: This Paper is contribution no. 663 of the Centre for Estuarine and Coastal Ecology, Netherlands Institute of Ecology.

\section{LITERATURE CITED}

Andersen, K. P. \& Ursin, E., 1977. A multispecies extension to the Beverton and Holt theory of fishing, with accounts of phosphorus circulation and primary production. - Meddr Danm. Fisk.og Havunders. 7, 319-435.

Anonymous, 1986. Fifth report of the Benthos Ecology Working Group. - C. M./ICES, L 27, 1-33.

Basford, D. J. \& Eleftheriou, A., 1988. The benthic environment of the North Sea $\left(56^{\circ}\right.$ to $\left.61{ }^{\circ} \mathrm{N}\right),-\mathrm{J}$. mar. biol. Ass. U. K. 68, 125-141.

Basford, D. J., Eleftheriou, A. \& Raffaelli, D., 1989. The epifauna of the northern North Sea $\left(56^{\circ}-61^{\circ} \mathrm{N}\right)$. - J. mar. biol. Ass. U. K. 69, 387-407.

Basford, D. J, Eleftheriou, A. \& Raffaelli, D., 1990. The infauna and epifauna of the northern North Sea. - Neth. J. Sea Res. 25, 166-173. 
Clarke, A., 1992. Is there a latitudinal diversity cline in the sea? - Trends Ecol. Evolut. 7, 286-287.

Eleftheriou, A. \& Basford, D. J., 1989. The macrobenthic infauna of the offshore northern North Sea. - J. mar. biol. Ass. U.K. 69, 123-143.

Fransz, H. G. \& Gieskes, W. N. C., 1984. The imbalance of phytoplankton and copepods in the North Sea. - Rapp. P.-v. Réun. Cons. int. Explor. Mer 183, 218-225.

Heip, C., Basford, D., Craeymeersch, J. A., Dewarumez, J.-M., Dörjes, J., de Wilde, P., Duineveld, G., Eleftheriou, A., Herman, P. M. J., Niermann, U., Kingston, P., Künitzer, A., Rachor, E., Rumohr, H., Soetaert, K. \& Soltwedel, T., 1992a. Trends in biomass, density and diversity of North Sea macrofauna. - ICES J. mar. Sci, 49, 13-22.

Heip, C., Basford, D., Craeymeersch, J. A., Dewarumez, J.-M., de Wilde, P., Dörjes, J., Duineveld, G., Eleftheriou, A., Herman, P. M. J., Huys, R., Irion, G., Niermann, U., Kingston, P., Künitzer, A., Rachor, E., Rumohr, H., Soetaert, K. \& Soltwedel, T., 1992b. The benthic communities of the North Sea. Summary of the results of the North Sea Benthos Survey as presented to the advisory Committee on Marine Pollution of the International Council for the Exploration of the Sea. ICES Coop. Res. Rep. 190, 148-175.

Hill, M. O., 1973. Diversity and evenness: a unifying notation and its consequences. - Ecology 54 , $427-432$.

Hill, M. O., 1979. TWINSPAN - a FORTRAN program for arranging multivariate data in an ordered two-way table by classification of the individuals and attributes. Cornell Univ., New York, $90 \mathrm{pp}$.

Huys, R., Herman, P. M. J., Heip, C. H. R. \& Soetaert, K., 1992. The meiobenthos of the North Sea: density, biomass trends and distribution of copepod communities. - ICES J. mar. Sci. 49, $23-44$.

Huys, R., 1992. The amphiatlantic distribution of Leptastacus macronyx (T. Scolt, 1892) (Copepoda Harpacticoida). - Meded. K. Acad. Wet. Lett.sch one Kunsten Belg. Kl. Wet. 54, 21-196.

Kirkegaard, J. B., 1969. A quantitative investigation of the central North Sea polychaeta. - Spolia zool. Mus. haun. 29, 1-185.

Krause, M., 1981. Vertical distribution of faecal pellets during FLEX 76. - Helgoländer Meeresunters. 34, 313-337.

Künitzer, A., Basford, D., Craeymeersch, J. A., Dewarumez, J. M., Dörjes, Duineveld, G. C. A., J., Eleftheriou, A., Heip, C., Herman, P. M. J., Kingston, P., Niermann, U., Rumohr, H. \& de Wilde, P. A. J., 1992. The benthic infauna of the North Sea: Species distribution and assemblages. - ICES J. mar. Sci. 49, 127-143.

Lee, A. J., 1980. North Sea: physical oceanography. In: The north-west European shelf seas. Ed, by F. T. Banner, M. B. Collins, K. S. Massie. Elsevier, Amsterdam, 2, 467-493.

Petersen, C. G. J., 1914. Valuation of the sea. II. The animal communities of the sea bottom and their importance for marine zoogeography. - Rep. Dan. Biol. Stn. 21, 1-44.

Petersen, C. G. J., 1918. The sea bottom and its production of fishfood. - Rep. Dan. biol. Stn $25,1-62$.

Petersen, G. H., 1977. The density, biomass and origin of the bivalves of the central North Sea. Meddr Danm. Fisk.- og Havunders. 7, 221-273.

Rachor, E., 1982. Biomass distribution and production estimates of macro-endofauna in the North Sea. - ICES CM 1982/L:2, $11 \mathrm{pp}$.

Steele, J. H., 1967. Notes on some theoretical problems in production ecology. - Memorie Ist. ital. Idrobiol. 18 (Suppl.), 383-398.

Steele, J. H., 1974. The structure of marine ecosystems. Blackwell, Oxford, $128 \mathrm{pp}$.

Stehli, F. G., McAlester A. L. \& Helsley, C. E., 1967. Taxonomic diversity of recent bivalves and some implications for geology. - Bull. geol. Soc. Am., 78, 455-466.

Tomczak, G. \& Goedecke E., 1962. Monatskarten der Temperatur der Nordsee, dargestellt für verschiedene Tiefenhorizonte. - Dt. hydrog. Z. Erg.-H. (Reihe B) 7.

Thorson, G., 1957. Bottom communities (sublittoral or shallow shelf). In: Treatise on marine ecology and palaeoecology. Ed. by J. W. Hedgpeth. Geol. Soc. of America, New York, 461-534.

Ursin, E., 1960. A quantitative investigation of the echinoderm fauna of the central North Sea. Meddr. Danm. Fisk.- og Havunders. 2, 1-204.

Wells, J. B. J., 1986. Copepoda: marine-interstitial Harpacticoida. In: Stygofauna mundi. Ed. by L. Botosaneanu. Brill, Leîden, 356-381. 